\title{
Soil Test based Fertilizers Recommendation of NPK for Mulberry (Morus alba L.) Farming in Acid Soils of Lohardaga, Jharkhand, India
}

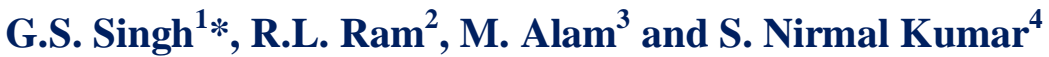 \\ ${ }^{1}$ Research Extension Centre (Sub Unit), Central Silk Board, Bhandra- 835306, \\ Lohardaga, Jharkhand, India \\ ${ }^{2}$ Regional Sericultural Research Station, Central Silk Board, Kalimpong-734301, \\ Darjeeling, W.B. India \\ ${ }^{3}$ Regional Sericultural Research Station, Central Silk Board, Nagri - 835303, \\ Ranchi, Jharkhand, India \\ ${ }^{4}$ Central Sericultural Research and Training Institute, Central Silk Board, \\ Berhampore-7421.Murshidabad, W.B., India \\ *Corresponding author
}

Keywords Mulberry, Soil Fertility, Acid soils, Soil test based dose of fertilizers, Mulberry leaf yield.

\begin{tabular}{l}
\hline Article Info \\
\hline Accepted: \\
16 May 2016 \\
Available Online: \\
10 June 2016
\end{tabular}

\section{A B S T R A C T}

The assessment of fertility status of the soils was carried out in the year 2012-13 at 30 farmers' field from 7 different villages namely Hondaga, Baratpur, Jamgai, Dumari, Nawdiha, Bhauro and Saranatoli villages of Lohardaga district Jharkhand to apply the soil test based recommendation of NPK for Mulberry (Morus alba L.) farming in acid soils of Lohardaga, Jharkhand. Application of NPK among farmers' field were categorized into farmers existing practices (FEP), recommended practices (RP) and soil test based fertilizer application (STBFA). STBFA of NPK was applied on the basis of ready reckoner developed by the Central Sericultural Research \& Training Institute, Berhampore (Table 1). Based on soil analysis, soils of this area have been characterized as problematic soils. The soil $\mathrm{pH}$ among the villages stated above ranged from 4.32 to 5.07 which can be classified as very strong to strong active acidity. The organic carbon content ranged from 0.36 to 0.69 percent which can be reported under low to medium. The available nitrogen content ranged from $119.80 \mathrm{~kg} \mathrm{ha}^{-1}$ to $194.67 \mathrm{~kg} \mathrm{ha}^{-1}$ whereas available phosphorus and potassium ranged from 10.80 to $15.60 \mathrm{~kg} \mathrm{ha}^{-1}$ and 224.44 to $306 \mathrm{~kg} \mathrm{ha}^{-1}$ respectively (Table 2). While, going through the leaf yield gain percent among the farmers field in the 7 villages, it was found that, nutrient management under STBFA was highly significant as compare to the FEP followed by RP. The average leaf yield gain was recorded from 10.86 percent to 15.29 percent among the entire farmers field. 


\section{Introduction}

Mulberry (Morus spp) is an economically and traditionally very important deciduous plant for the development of sericulture industry. It belongs to the family Moraceae and is successfully grown under tropical to temperate climatic conditions in various part of the country. Mulberry leaves are basic food material for silkworm Bombyx mori $\mathrm{L}$. The nutritious leaves are the most important growth regulating factors for these silkworms, because, being a monophagous insect, they derive almost all the essential nutrients from the mulberry leaves for their survival. Hence, good quality of nutritious mulberry leaves should be feed in abundant quantity for the quality silkworm seed and cocoon production.

It is the well known fact that, the production and productivity of quality mulberry leaves depends on soil health, environmental condition and farm management practices where soil is the mother of whole things and its management practices cannot be ignored or postponed for the survival of life. It is also well known fact that the soil testing is the most effective array in the arsenal of the farmers and planners to detect and deliver the correct doses of nutrients required by the plants.

Keeping the fact in the mind and importance of sericulture industry, this research work were initiated in 2012-13 at 30 farmers' field from 7 different villages of Lohardaga, Jharkhand for the assessment of fertility status to apply the soil test based doses of NPK in Mulberry (Morus alba L.) farming.

\section{Materials and Methods}

Lohardaga district, the western part of the Ranchi plateau come into existence in 1983. It is bounded by Latehar district in north, Gumla in south and west and Ranchi in the east. It extends from $23^{0} 16^{\prime} 45^{\prime}$, to $23^{\circ} 40^{\prime} 30^{\prime}, \mathrm{N}$ latitude and $84^{0} 23^{\prime} 50$ ' to $84^{0} 56^{\prime} 50^{\prime}$ E longitude. Physiologically, the district has been divided into hilly tract and the plateau region. The hilly tract is extended in the west and north western part of the district, whereas the high hill tops of the region is known as pat. The plateau region is the part of the Gumla plateau comprised with entire part of Lohardaga and Bhandra.

Geologically, the area is comprised with Archean granites and gneisses. Alluvium of recent to sub-recent age is also found in the river valley. The main rivers of the districts are South Koel, Sankh, Nandini, Chaupat and Fulijhar etc. Rainfed cultivation is the general agricultural practices in the district. The annual average temperature is $23{ }^{0} \mathrm{C}$; the highest temperature goes to $36{ }^{0} \mathrm{C}$ in summer and lowest of $10{ }^{0} \mathrm{C}$ in winter. The district receives annual rainfall of 1000 to $1600 \mathrm{~mm}$ and it increases from west to east.

The assessment of fertility status of the soils was carried out in the year 2012-13 at 30 farmers' field from 7 different villages namely Hondaga, Baratpur, Jamgai, Dumari, Nawdiha, Bhauro and Saranatoli villages of Lohardaga district Jharkhand to apply the soil test based doses of NPK in Mulberry (Morus alba L.) farming. Soil samples were collected, dried, sieved and analyzed by adopting the standard procedure (Black, 1985; Jackson, 1979).

Application of NPK among farmers' field were categorized into farmers existing practices (FEP), recommended practices (RP) and soil test based doses (STBD). STBD of NPK was applied on the basis of ready reckoner developed by the Central Sericultural Research \& Training Institute, Berhampore. Leaf yield data was recorded in the month of March, 2013; August, 2013 and October, 2013. There was no regularity 
and similarity of farmers existing practices for NPK application, whereas the recommended doses of NPK for rainfed mulberry farming is 150:50:50, hence, the same doses of NPK were applied under recommended practices. Soil Test based doses of NPK is given in Table 1.

\section{Result and Discussion}

\section{Fertility Status of Soils}

Based on soil analysis, soils of this area have been characterized as problematic soils. The soil $\mathrm{pH}$ among the villages stated above ranged from 4.32 to 5.07 which can be classified as very strong to strong active acidity. The organic carbon content ranged from 0.36 to 0.69 percent which can be reported under low to medium. While, analyzing the NPK availability among the soils of these villages, it was found that, the deficiency of these nutrients in this area was also major problem. The available nitrogen content ranged from $119.80 \mathrm{~kg} \mathrm{ha}^{-1}$ to $194.67 \mathrm{~kg} \mathrm{ha}^{-1}$ whereas available phosphorus and potassium ranged from 10.80 to 15.60 $\mathrm{kg} \mathrm{ha}$ and 224.44 to $306 \mathrm{~kg} \mathrm{ha}^{-1}$ respectively. Details of data regarding fertility status of soils are given in table 2 .

Soil $\mathrm{pH}$ is the most important soil health indicator and all the nutrient availability chemistry within the soils depends on the soil $\mathrm{pH}$. Soil $\mathrm{pH}$ is also considered as master variable in soils, because, it controls many chemical processes that take place. Likewise, organic carbon content is also most important soil health indicator which improves the morpho-physico-chemical properties of soil. While describing the soils health data among the villages as stated in Table 2, it was found that the soils of these villages are highly acidic with low fertility status, hence, the adoption of nutrient management practices was most challenging issue.
Nitrogen is an essential macronutrient needed by all plants to thrive. It is an important component of many structural, genetic and metabolic compounds in plant cells. It is also one of the basic components of chlorophyll, the compound by which plants use sunlight energy to produce sugars during the process of photosynthesis.

Being an essential macronutrient, the availability of nitrogen among these villages are low to medium. Considering the range $<272 \mathrm{~kg} \mathrm{ha}^{-1}$ 'low', 272-544 kg ha-1 'medium' and $>544 \mathrm{~kg} \mathrm{ha}^{-1}$ 'high' (Baruah and Barthakur, 1997), the soils of all the villages have low to medium available nitrogen content.

Next to nitrogen, phosphorus is very important essential nutrients for plant growth and is found in every living plant cell. It is involved in several key plant functions, including energy transfer, photosynthesis, transformation of sugars and starches, nutrient movement within the plant and transfer of genetic characteristics from one generation to the next. Considering the range $<22.5 \mathrm{~kg} \mathrm{ha}^{-1}$ 'low', 22.5-56.0 kg ha 'medium' and $>56.0 \mathrm{~kg} \mathrm{ha}^{-1}$ 'high' (Baruah and Barthakur, 1997), the soils of this area was very low to low.

Potassium is third essential macronutrients. Like nitrogen, potassium is absorbed by plants in significantly larger quantities than any other nutrient. It accumulates mainly in vacuole and cytoplasm without forming organic matter in cells and play very important role in the plant metabolism, resistance to lodging, frost, winter-hardiness and prevention from the disease and pests etc.

Considering the range $<136.0 \mathrm{~kg} \mathrm{ha}^{-1}$ 'low', $136.0-338.0 \mathrm{~kg} \mathrm{ha}^{-1}$ 'medium' and $>338.0 \mathrm{~kg}$ ha $^{-1}$ 'high' (Baruah and Barthakur, 1997), the soils of this area was low to medium. 
Various workers from entire parts of the country reported that the leaching of bases, intensive weathering and sloping landforms was major factors in the variation of $\mathrm{pH}$ with depths, physiography and terrace (Ram et al., 2013; Ram et al., 2010; Nayak et al., 2002; Patagundi et al., 1996, Bhadrapur and Seshagiri Rao, 1979). Brady and Weil, (1999) defined, soil organic matter as the summation of plant and animal residues at various stages of decomposition, cells and tissues of soil organisms, and welldecomposed substances, whereas, Woomer et al., (1994) opined that, the OC regulates the soil properties.
Albrecht et al., (1997) also stated that, the soil $\mathrm{pH}$, cultural practices and application of manures and fertilizers have had long term effects on soil organic matter by breaking up the organic residues which helps to stimulate the microbial activity and increasing soil organic matter decomposition. He further described that the fertilizer applications can also result in an increase in soil organic matter levels due to greater yields creating a larger return of crop residues to the soil. The combined application of organic manures and inorganic fertilizers increased the organic carbon content in Darjeeling tea soils over the initial values (Singh et al., 2011; Hegde, 1996).

Table.1 Soil Test based doses of NPK

\begin{tabular}{|c|c|c|c|c|c|}
\hline \multirow{2}{*}{$\begin{array}{l}\text { Sl. } \\
\text { No. }\end{array}$} & \multirow{2}{*}{$\begin{array}{l}\text { Village } \\
\text { Name }\end{array}$} & \multirow{2}{*}{$\begin{array}{c}\text { Total No. } \\
\text { of farmers } \\
\end{array}$} & & \multicolumn{2}{|c|}{ Soil test Based Doses of fertilizers } \\
\cline { 4 - 6 } & & & & & \\
& covered & Nitrogen & Phosphorus & Potash \\
\hline 1 & Hondaga & 5 & $90.37 \pm 5.44$ & $62.96 \pm 1.41$ & $23.95 \pm 0.67$ \\
\hline 2 & Baratpur & 5 & $78.51 \pm 10.50$ & $59.53 \pm 1.48$ & $31.73 \pm 4.55$ \\
\hline 3 & Jamgai & 9 & $57.97 \pm 1.58$ & $55.73 \pm 1.23$ & $41.95 \pm 3.23$ \\
\hline 4 & Dumari & 5 & $58.56 \pm 1.01$ & $53.16 \pm 1.26$ & $26.99 \pm 4.13$ \\
\hline 5 & Nawdiha & 2 & $75.55 \pm 0.25$ & $52.40 \pm 4.51$ & $22.47 \pm 1.48$ \\
\hline 6 & Bhauro & 3 & $60.00 \pm 7.61$ & $58.93 \pm 2.02$ & $25.27 \pm 0.87$ \\
\hline 7 & Saranatoli & 1 & 79.75 & 58.89 & 16.91 \\
\hline
\end{tabular}

Table.2 Fertility status of soils

\begin{tabular}{|c|c|c|c|c|c|c|c|}
\hline \multirow{2}{*}{$\begin{array}{l}\text { Sl. } \\
\text { No. }\end{array}$} & \multirow{2}{*}{$\begin{array}{l}\text { Village } \\
\text { Name }\end{array}$} & \multirow{2}{*}{$\begin{array}{c}\text { Total No. } \\
\text { of farmers } \\
\text { covered }\end{array}$} & \multicolumn{5}{|c|}{\begin{tabular}{|c|} 
Fertility status of soils \\
\end{tabular}} \\
\hline & & & pH $(1: 2.5)$ & $\begin{array}{c}\text { Organic } \\
\text { carbon }(\%)\end{array}$ & $\begin{array}{c}\text { Available N (kg } \\
\left.\text { ha }^{-1}\right)\end{array}$ & $\begin{array}{c}\text { Available P (kg } \\
\left.\text { ha }^{-1}\right)\end{array}$ & $\begin{array}{c}\text { Available K } \\
\left(\mathrm{kg} \mathrm{ha}^{-1}\right)\end{array}$ \\
\hline 1 & Hondaga & 5 & $4.57 \pm 0.11$ & $0.38 \pm 0.04$ & $119.80 \pm 13.87$ & $10.80 \pm 1.56$ & $302.20 \pm 2.92$ \\
\hline 2 & Baratpur & 5 & $4.32 \pm 0.19$ & $0.49 \pm 0.04$ & $149.60 \pm 20.69$ & $11.40 \pm 1.08$ & $269.20 \pm 18.69$ \\
\hline 3 & Jamgai & 9 & $4.72 \pm 0.07$ & $0.50 \pm 0.03$ & $194.67 \pm 4.21$ & $13.89 \pm 0.73$ & $224.44 \pm 11.85$ \\
\hline 4 & Dumari & 5 & $4.97 \pm 0.02$ & $0.45 \pm 0.09$ & $192.80 \pm 2.71$ & $15.60 \pm 0.75$ & $288.20 \pm 16.36$ \\
\hline 5 & Nawdiha & 2 & $4.99 \pm 0.02$ & $0.36 \pm 0.07$ & $148.50 \pm 2.89$ & $15.50 \pm 2.50$ & $306.00 \pm 8.00$ \\
\hline 6 & Bhauro & 3 & $5.07 \pm 0.07$ & $0.52 \pm 0.01$ & $189.00 \pm 19.67$ & $11.67 \pm 1.33$ & $294.67 \pm 3.53$ \\
\hline 7 & Saranatoli & $\mathbf{1}$ & 4.78 & 0.69 & 163.0 & 12.0 & 229.0 \\
\hline
\end{tabular}


Table.3 Leaf Yield data

\begin{tabular}{|c|c|c|c|c|c|c|c|c|c|c|c|c|c|c|c|c|}
\hline \multirow{2}{*}{$\begin{array}{l}\text { Sl. } \\
\text { No. }\end{array}$} & \multirow[t]{2}{*}{$\begin{array}{l}\text { Village } \\
\text { Name }\end{array}$} & \multirow[t]{2}{*}{$\begin{array}{l}\text { No.of } \\
\text { farmers }\end{array}$} & March & August & October & Total & March & August & October & Total & March & August & October & Total & $\begin{array}{l}\text { Yield gain in } \\
\text { recommend }\end{array}$ & $\begin{array}{l}\text { Yield gain } \\
\text { in STBFA }\end{array}$ \\
\hline & & & \multicolumn{4}{|c|}{ Leaf yield $\left(\mathrm{mt} \mathrm{ha}^{-1}\right)$ in existing practices } & \multicolumn{4}{|c|}{ Leaf yield $\left(\mathrm{mt} \mathrm{ha}^{-1}\right)$ in recommended practices } & \multicolumn{4}{|c|}{ Leaf yield $\left(\mathrm{mt} \mathrm{ha}^{-1}\right)$ in STBFA } & ed $(\%)$ & $(\%)$ \\
\hline 1 & Hondaga & 5 & $2.76 \pm 0.06$ & $2.94 \pm 0.05$ & $2.85 \pm 0.04$ & $8.54 \pm 0.07$ & $2.93 \pm 0.05$ & $3.10 \pm 0.02$ & $3.08 \pm 0.01$ & $9.12+0.06$ & $3.02 \pm 0.05$ & $3.17 \pm 0.03$ & $3.17 \pm 0.02$ & $9.36 \pm 0.10$ & $3.56 \pm 0.51$ & $10.86 \pm 0.86$ \\
\hline 2 & Baratpur & 5 & $2.77 \pm 0.07$ & $2.79 \pm 0.05$ & $2.75 \pm 0.04$ & $8.31 \pm 0.10$ & $2.99 \pm 0.05$ & $3.09 \pm 0.04$ & $3.05 \pm 0.04$ & $9.12+0.09$ & $3.08 \pm 0.05$ & $3.17 \pm 0.05$ & $3.13 \pm 0.02$ & $9.38 \pm 0.10$ & $2.80 \pm 0.36$ & $12.72 \pm 2.15$ \\
\hline 3 & Jamgai & 9 & $3.00 \pm 0.05$ & $3.13 \pm 0.10$ & $2.94 \pm 0.08$ & $9.06 \pm 0.16$ & $3.06 \pm 0.03$ & $3.10 \pm 0.07$ & $3.09 \pm 0.05$ & $9.25+0.10$ & $3.13 \pm 0.04$ & $3.14 \pm 0.06$ & $3.10 \pm 0.06$ & $9.36 \pm 0.11$ & $3.39 \pm 0.39$ & $11.45 \pm 0.96$ \\
\hline 4 & Dumari & 5 & $3.00 \pm 0.04$ & $2.94 \pm 0.04$ & $2.83 \pm 0.06$ & $8.77 \pm 0.12$ & $3.16 \pm 0.02$ & $3.18 \pm 0.02$ & $3.10 \pm 0.03$ & $9.45+0.06$ & $3.25 \pm 0.01$ & $3.28 \pm 0.02$ & $3.23 \pm 0.03$ & $9.76 \pm 0.04$ & $3.30 \pm 0.25$ & $11.29 \pm 0.98$ \\
\hline 5 & Nawdiha & 2 & $3.01 \pm 0.02$ & $2.87 \pm 0.06$ & $2.68 \pm 0.01$ & $8.56 \pm 0.03$ & $3.13 \pm 0.01$ & $3.14 \pm 0.03$ & $3.10 \pm 0.04$ & $9.37+0.06$ & $3.23 \pm 0.01$ & $3.22 \pm 0.02$ & $3.18 \pm 0.02$ & $9.64 \pm 0.04$ & $2.86 \pm 0.31$ & $12.59 \pm 0.01$ \\
\hline 6 & Bhauro & 3 & $3.00 \pm 0.10$ & $2.84 \pm 0.07$ & $2.76 \pm 0.05$ & $8.60 \pm 0.20$ & $3.20 \pm 0.02$ & $3.20 \pm 0.02$ & $3.11 \pm 0.01$ & $9.50+0.03$ & $3.28 \pm 0.02$ & $3.27 \pm 0.01$ & $3.22 \pm 0.01$ & $9.76 \pm 0.03$ & $2.68 \pm 0.15$ & $13.62 \pm 2.55$ \\
\hline 7 & Saranatoli & 1 & 3.12 & 2.70 & 2.69 & 8.50 & 3.21 & 3.20 & 3.15 & 9.56 & 3.31 & 3.27 & 3.23 & 9.80 & 2.55 & 15.29 \\
\hline
\end{tabular}


Vijay Kumar et al., (1994) reported that, the low availability of phosphorus was may be due to fixation of released phosphorus by clay minerals and oxides of $\mathrm{Fe}$ and $\mathrm{Al}$ whereas various workers from all over the country also reported that the, availability of potash in the soils depends on weathering of $\mathrm{K}$ bearing minerals and also release of $\mathrm{K}$ from organic residues (Rao et al., 2008).

\section{Mulberry Leaf Yield}

While studying the season and village wise leaf yield data, it was found that, the average higher leaf yield was recorded in all the villages during entire crop season i.e. March, August, and October by applying the STBD of NPK followed by RP and FEP. The higher leaf yield $9.12 \mathrm{mt} \mathrm{ha}^{-1}$ was recorded in the Hondaga village with the application of soil test based doses of fertilizer application (STBFA) followed by $9.36 \mathrm{mt} \mathrm{ha}^{-1}$ in recommended practices (RP) and $8.54 \mathrm{mt} \mathrm{ha}^{-1}$ in farmers existing practices (FEP). In the Bratpur farmer's field, the maximum leaf yield was recorded $9.38 \mathrm{mt}$ $\mathrm{ha}^{-1}$ in STBFA, 9.12 $\mathrm{mt} \mathrm{ha}^{-1}$ in RP and 8.31 $\mathrm{mt} \mathrm{ha}^{-1} \mathrm{FEP}$. The leaf yield data of Jamgai farmers was also similar and it was $9.36 \mathrm{mt}$ $\mathrm{ha}^{-1}$ in STBFA, $9.25 \mathrm{mt} \mathrm{ha}^{-1}$ in RP and 9.06 $\mathrm{mt} \mathrm{ha}^{-1}$ FEP.

In Dumari farmers maximum leaf yield was recorded $9.76 \mathrm{mt} \mathrm{ha}^{-1}$ in STBFA, $9.45 \mathrm{mt}$ ha ${ }^{1}$ in RP and $8.77 \mathrm{mt} \mathrm{ha}^{-1}$ in FEP. In Nawdiha farmers maximum leaf yield was recorded 9.64 $\mathrm{mt} \mathrm{ha}^{-1}$ in STBFA, $9.37 \mathrm{mt} \mathrm{ha}^{-1}$ in RP and $8.56 \mathrm{mt} \mathrm{ha}^{-1}$ in FEP. In Bhauro farmers maximum leaf yield was recorded $9.76 \mathrm{mt}$ $\mathrm{ha}^{-1}$ in STBFA, 9.50_ $\mathrm{mt} \mathrm{ha}^{-1}$ in RP and $8.60 \mathrm{mt} \mathrm{ha}^{-1}$ in FEP. In Saranatoli farmers maximum leaf yield was recorded $9.8 \mathrm{mt}$ ha ${ }^{1}$ in STBFA, in recommended practices 9.56 $\mathrm{mt} \mathrm{ha} \quad \& 8.50$ Leaf yield $\left(\mathrm{mt} \mathrm{ha}{ }^{-1}\right)$ in existing practices was recorded.
While, going through the leaf yield gain percent among all the villages, it was found that, nutrient management under STBFA was highly significant as compare to the FEP followed by RP. The average leaf yield gain was recorded from 10.86 percent to 15.29 percent among the entire farmers field.

It can be concluded that the soil test based doses of fertilizers were most efficient and it was beneficial to increase the yield and quality of mulberry leaves.

\section{References}

Albrecht, S.L., H.L.M. Baune, P.E. Rasmussen, C.L. Douglas, Jr. 1997. Light fraction soil organic matter in long-term agro ecosystems. Columbia Basin Agri. Res. Annual Report. Spec. Rpt., 977: 38-42.

Baruah, T.C., Barthakur, H.P. 1997. A Textbook of Soil Analysis. Vikas Publishing House, New Delhi.

Bhadrapur, T.G., Seshagiri Rao, T. 1979. The effect of seepage and water logging on the development of saline and sodic soils in Tungabhadra Project Area of Karnataka. J. Indian Soc. Soil Sci., 27: 408-413.

Black, C.A. 1985. Methods of Soil Chemical Analysis - Part 2. American Society of Agronomy, Madison, Wisconsin, USA.

Brady, N.C., R.R. Weil. 1999. The Nature and Properties of Soils, $12^{\text {th }}$ Edition. Upper Saddle River, NJ: PrenticeHall, Inc. 881p.

Hegde, O.M. 1996. Integrated nutrient supply on crop productivity and soil fertility in rice (Oryza sativa) system. Indian J. Agron., 41(1): 1-8.

Jackson, M.L. 1979. Soil Chemical Analysis: Advance Course. University of Wisconsin, Madison and 
Wisconsin.

Nayak, R.K., Sahu, G.C., Nanda, S.S.K. 2002. Characterization and classification of the soils of Central Research Station, Bhubaneswar. Agropedol., 12: 1-8.

Patagundi, M.S., Channal, H.T., Satyanarayana, T. 1996.

Characteristics of some salt affected soils of Tungabhadra Left Bank Command, Karnataka. Karnataka J. Agri. Sci., 9: 226-230.

Ram, R.L., Jha, P., Sharma, P.K., Ahmed, N., Kumar, R., Sharanappa., Vasudeo Rao, D.A.L., Singh, V. 2013. Mapping and Assessment of Soils in Nagarjunasagar Catchment, Lingasugur Taluk of Karnataka. Int. J. Agri. Sci., 5(2): 347-353.

Ram, R.L., Sharma, P.K., Jha, P., Das, S.N., Ahmad, N. 2010. Characterization and classification of soils of Nagarjunasagar catchment in Shorapur taluk of Gulbarga district,
Karnataka state. Agropedol., 20(2): 112-123.

Rao, A.P.V., Naidu, M.V.S., Ramavatharam, N., Rao, G.R. 2008. Characterization, classification and evaluation of soils on different land forms in Ramachandrapuram mandal of Chittur district in Andhra Pradesh for sustainable land use planning. $J$. Indian Soc. Soil Sci., 56(1): 23-33.

Singh, A.K., Bisen, J.S., Bora, D.K., Kumar, R., Bera, B. 2011. Comparative study of organic, inorganic and integrated plant nutrient supply on the yield of Darjeeling tea and soil health. Two and a Bud, 58: 58-61.

Woomer, P.L., Martin, A., Albrecht, A., Reseck, D.V.S., Scharpenseel, H.W. 1994. The importance and management of soil organic matter in the tropics. In: Woomer PL, Swift MJ (eds) The biological management of tropical soil fertility. Wiley, Chichester.

\section{How to cite this article:}

G.S. Singh, R.L. Ram, M. Alam and S. Nirmal Kumar. 2016. Soil Test based Fertilizers Recommendation of NPK for Mulberry (Morus alba L.) Farming in Acid Soils of Lohardaga, Jharkhand, India. Int.J.Curr.Microbiol.App.Sci. 5(6): 392-398. doi: http://dx.doi.org/10.20546/ijcmas.2016.506.045 